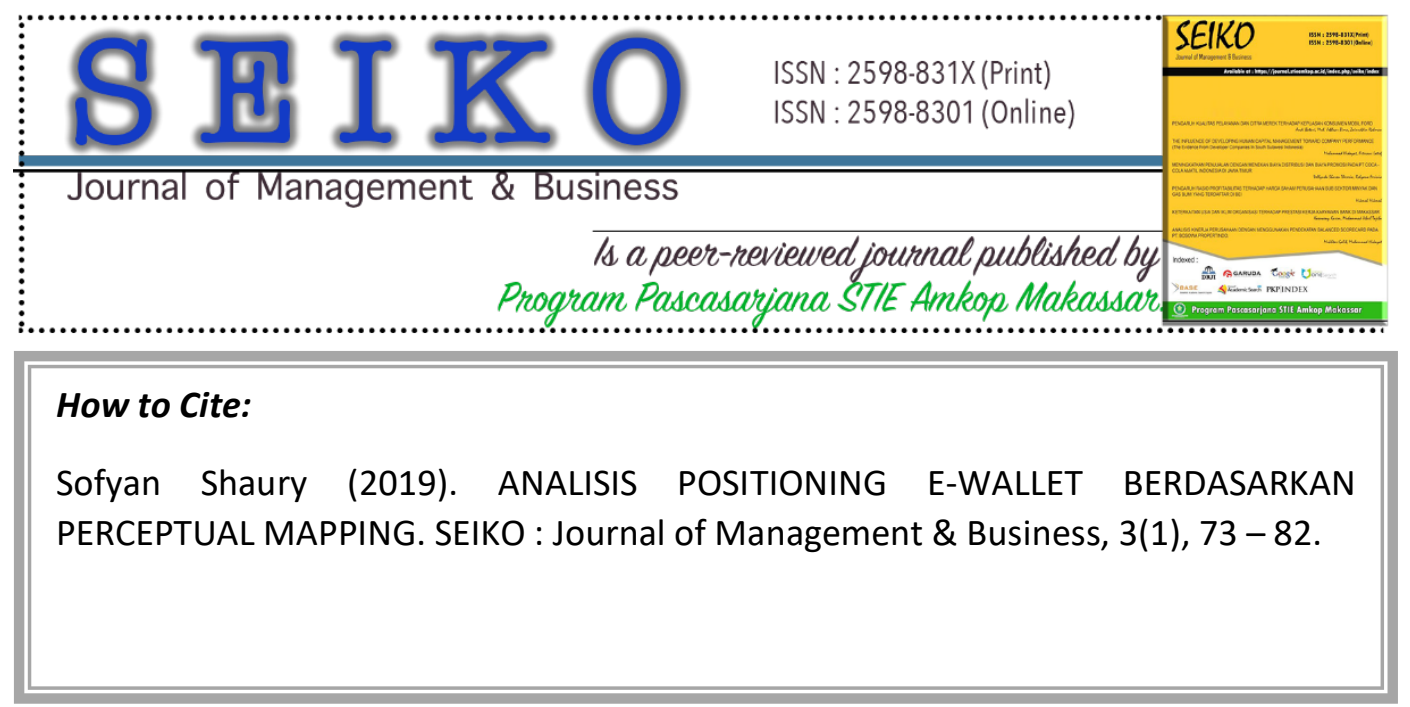

\title{
ANALISIS POSITIONING E-WALLET BERDASARKAN PERCEPTUAL MAPPING
}

\section{Positioning Analysis of E-Wallet Based on Perceptual Mapping}

\author{
Sofyan Shaury \\ Manajemen, Fakultas Ekonomi dan Bisnis, Universitas Airlangga, Surabaya \\ Email: sofyanshaury29@gmail.com
}

\begin{abstract}
ABSTRAK
Indonesia adalah salah satu negara di kawasan Asia Tenggara di mana pertumbuhan ekonomi semakin membaik. Industri digital di Indonesia terus menunjukkan perkembangannya. Dampak dari kemajuan ini menghadirkan inovasi di bidang pembayaran digital. Penelitian ini dilakukan dengan metode kuantitatif dan sampel berasal dari individu yang menggunakan salah satu e-wallet dan mengetahui semua e-wallet selain yang digunakan, sebanyak 137 responden. Penelitian ini menggunakan teknik analisis korespondensi dengan SPSS23. Hasil analisis korespondensi adalah bahwa setiap dompet elektronik memiliki kelebihannya sendiri yang tidak dimiliki dompet elektronik lain. Selain itu Dimensi 1 (d1) aman, dan Dimensi 2 (d2) mudah digunakan. Dalam atribut manfaat OVO lebih unggul dari ewallet lainnya, atribut keamanan dapat dilihat DOKU lebih unggul dari e-wallet lainnya dan atribut GOPAY kemudahan penggunaan dan e-wallet kedua DANA dianggap oleh konsumen sama dalam hal kelebihan yang dibawanya. GOPAY
\end{abstract}


diketahui bahwa e-wallet memiliki kemudahan menggunakan yang terbaik di antara atribut lainnya dengan pesaing terdekatnya DANA, OVO diketahui bahwa e-wallet memiliki kelebihan di antara atribut lainnya, OVO harus membuat strategi untuk merespons persaingan dengan GOPAY dan LINK AJA. LINK AJA cenderung dianggap oleh konsumen dalam kondisi netral antara keamanan dan kemudahan penggunaan dan DANA diketahui bahwa e-wallet memiliki kemudahan penggunaan.

Kata kunci: "Positioning, e-wallet, analisis korespondensi".

\begin{abstract}
Indonesia is one of the countries in the Southeast Asian region where economic growth is getting better. The digital industry in Indonesia continues to show its development. The impact of this progress presents innovation in the realm of digital payments. This research was conducted with quantitative methods and samples came from individuals who used one of the e-wallets and knew all e-wallets other than those used, as many as 137 respondents. This study uses correspondence analysis techniques with SPSS23. The result of the correspondence analysis is that each e-wallet has its own advantages that other e-wallets do not have. Besides that Dimension $1(d 1)$ is security, and Dimension $2(d 2)$ is ease of use. In the benefits attribute OVO is superior to other e-wallets, security attributes can be seen DOKU is superior to other e-wallets and attributes of GOPAY ease of use and the second ewallet DANA is considered by consumers to be similar in terms of the advantages it carries. GOPAY is known that the e-wallet has the ease of using the best among other attributes with its closest competitor DANA, OVO is known that the e-wallet has benefits among other attributes, OVO must make a strategy to respond to competition with GOPAY and LINK AJA. LINK AJA tend to be perceived by consumers in neutral conditions between security and ease of use and DANA is known that the e-wallet has ease of use.
\end{abstract}

Keywords: "Positioning, e-wallet, correspondence analysis".

\title{
PENDAHULUAN
}

Negara Indonesia merupakan salah satu negara yang berada di kawasan Asia Tenggara yang tingkat pertumbuhan perekonomian semakin baik, selain itu kemudahan berinvestasi ini juga menjadi salah satu fokus pemerintah yang dituangkan dalam paket kebijakan ekonomi. semakin mudah akan mendorong banyak industri yang berkembang dan berinovasi di Indonesia, salah satunya industri digital. Yuliastuti (2017) mengemukakan industri digital di Indonesia terus memperlihatkan perkembangannya. Dampak kemajuan ini menghadirkan inovasi di 
ranah pembayaran digital. Jenisnya, seperti uang elektronik. Kini masyarakat Indonesia, terutama di wilayah perkotaan mulai akrab dan mengenal adanya pembayaran nontunai atau secara elektronik.

Dac-Nhuong Le dkk., (2019) E-wallet adalah salah satu tipe dari pembayaran elektronik, yang dapat digunakan untuk transaksi secara online melalui komputer atau Smartphone. E-Wallet menyediakan solusi yang sangat nyaman untuk bisnis apa pun, dan memungkinkan pelanggannya untuk membeli produk mereka secara online. E-wallet dalam bentuk digital terdapat pada perangkat seluler. Junaidi dan Sfenriato (2015) mengatakan, melalui e-wallet konsumen hanya perlu masukkan informasi satu kali dan dapat digunakan di situs mana saja untuk bertransaksi.

Perkembangan e-wallet yang sangat cepat dan banyak berdampak pada persaingan antar penyedia e-wallet semakin kompetitif, persaingan tersebut akan menimbulkan banyak perusahaan memberikan layanan-layanan beragam dan menjaga kualitas pelayanan agar berdampak positif pada kepuasan konsumen (Batari dkk, 2018), supaya dapat mengadopsi e-wallet. Maka perlu adanya strategi positioning untuk penyedia e-wallet agar mendapatkan posisi di benak konsumennya. Kotler dan Keller (2016: 297-298) menyatakan Positioning adalah tindakan mendesain penawaran dan citra perusahaan untuk menempati tempat berbeda di benak target pasar. Tujuannya untuk menemukan merek di benak konsumen, sehingga dapat memaksimalkan potensi manfaat bagi perusahaan.

Oleh karena itu, dalam melakukan positioning perlu adanya pemantauan dan evaluasi terhadap posisi e-wallet, apakah posisi tersebut perlu diperkuat atau justru diubah. Salah satu cara yang dapat dilakukan adalah melalui perceptual mapping. Hasil dari perceptual mapping dapat ditindaklanjuti untuk merumuskan strategi guna meningkatkan keuntungan bagi perusahaan. Selain itu pentingnya menggunakan strategi positioning, akan menciptakan suatu gambaran yang jelas mengenai apa dan bagaimana e-wallet ini dipersepsikan oleh khalayak, sehingga keunggulan tiaptiap e-wallet dapat dioptimalkan dan meningkatkan pendapatan perusahaan kedepannya. Terkait hal tersebut perlu dilakukan penelitian mengenai "analisis positioning e-wallet di Indonesia".Berdasarkan uraian yang telah dijabarkan, 
Perumusan permasalahan dalam penelitian adalah Bagaimana positioning e-wallet di Indonesia ditinjau dari atribut-atributnya?

\section{KAJIAN LITERATUR DAN PENGEMBANGAN MODEL Pemasaran}

Kotler dan Keller (2016: 27) mendefinsikan Pemasaran adalah tentang mengidentifikasi dan memenuhi kebutuhan manusia dan sosial. Salah satu definisi pemasaran tersingkat yang baik adalah "memenuhi kebutuhan secara menguntungkan." American Marketing Association menawarkan definisi formal berikut: Pemasaran adalah aktivitas, serangkaian institusi, dan proses untuk menciptakan, berkomunikasi, memberikan, dan bertukar penawaran yang memiliki nilai bagi pelanggan, klien, mitra, dan masyarakat luas. Mengatasi hal-hal ini. proses pertukaran membutuhkan banyak kerja dan keterampilan. Manajemen pemasaran terjadi ketika setidaknya satu pihak dalam suatu pertukaran potensial berpikir tentang cara untuk mencapai tanggapan yang diinginkan dari pihak lain, dengan demikian, manajemen pemasaran juga sebagai seni dan ilmu dalam memilih target pasar dan mendapatkan, menjaga, dan menumbuhkan pelanggan melalui menciptakan, memberikan, dan mengkomunikasikan nilai pelanggan yang unggul.

\section{Perilaku Konsumen}

Kotler dan Keller (2016: 179) mendefinsikan perilaku konsumen adalah studi tentang bagaimana individu, kelompok, dan organisasi memilih, membeli, menggunakan, dan membuang barang, jasa, ide, atau pengalaman untuk memuaskan kebutuhan dan keinginan mereka. Pemasar harus sepenuhnya memahami teori dan realitas tingkah laku konsumen.

\section{Uang Elektronik dan E-Payment}

Khoiriyah (2017) mengemukakan uang elektronik yang pertama kali muncul di Indonesia tahun 2007, tampil dalam bentuk e-money berbasis chip yang ditanam pada kartu atau media lain (chip based). Kebanyakan uang elektronik yang chip based sejauh ini tampil dalam bentuk kartu, sedangkan e-wallet adalah uang 
elektronik yang berbasis server (server based). Uang elektronik biasanya digunakan sebagai alat pembayaran secara elektronik. Shon dan Swatman (1998) mendefinisikan pembayaran elektronik (e-payment) sebagai setiap pertukaran dana yang diprakarsai melalui saluran komunikasi elektronik

\section{E-Wallet}

Dac-Nhuong Le dkk (2019) E-wallet adalah salah satu tipe dari pembayaran elektronik, yang dapat digunakan untuk transaksi secara online melalui komputer atau Smartphone. E-Wallet menyediakan solusi yang sangat nyaman untuk bisnis apapun, dan memungkinkan pelanggannya untuk membeli produk mereka secara online. E-wallet dalam bentuk digital terdapat pada perangkat seluler. Penelitian ini menggunakan 5 E-Wallet yaitu: GO PAY, OVO, LINK AJA, DOKU dan DANA. Adapun atribut atribut dalam penelitian ini yang terdiri dari: Manfaat, Keamanan dan Kemudahan penggunaan.

\section{Segmentation, Targeting, and Positioning (STP)}

Kotler dan Keller (2016: 31) menjelaskan salah satu dari core marketing concept yaitu, Target Market, Positioning dan Segmentation. Pemasar mengidentifikasi segmen pembeli yang berbeda dengan mengidentifikasi perbedaan demografis, psikografis, dan perilaku di antara mereka

\section{Positioning}

Kotler dan Keller (2016: 297-298) menyatakan Positioning adalah tindakan mendesain penawaran dan citra perusahaan untuk menempati tempat berbeda di benak target pasar. Tujuannya adalah untuk menemukan merek di benak konsumen untuk memaksimalkan potensi manfaat bagi perusahaan.

\section{Perceptual Mapping}

Hair dkk., (2014:520-521) menyatakan perceptual mapping adalah serangkaian teknik yang berusaha mengidentifikasi citra relatif yang dirasakan dari sekumpulan objek yang berupa perusahaan, produk, ide, atau item lain yang terkait 
dengan persepsi yang dimiliki secara umum. Tujuan dari setiap pendekatan pemetaan persepsi adalah untuk menggunakan penilaian konsumen atas kesamaan atau preferensi untuk mewakili objek, misalnya toko atau merek dalam ruang multidimensi. Model analisis yang akan menjadi kerangka konseptual dalam penelitian ini adalah sebagai berikut,

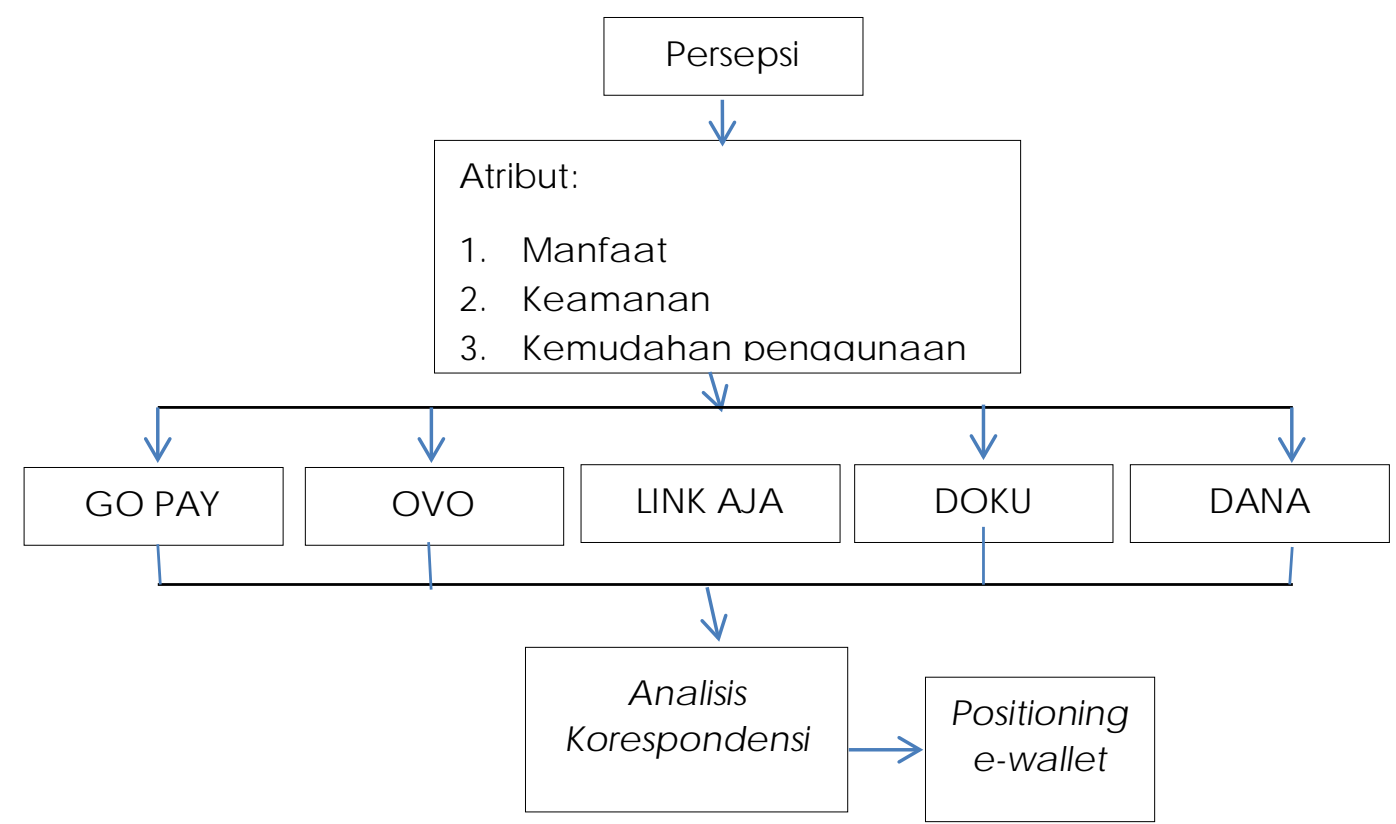

Gambar 1: Kerangka Berpikir

\section{METODE PENELITIAN}

\section{Penentuan Sampel}

Bungin (2011:111) mendefinisikan sampel adalah objek penelitian yang kecil dari populasi. Sampel atau partisipan dalam penelitian ini dipilih dengan menggunakan metode purposive sampling. Bungin (2011:125) mendefinisikan purposive sampling merupakan teknik digunakan pada penelitian-penelitian yang lebih mengutamakan tujuan penelitian daripada sifat populasi dalam menentukan sample penelitian. Sampel dalam penelitian menggunakan acuan Hair dkk., (2014) menyataan ukuran sampel untuk analisis multivariate jumlah sampel antar 100-200 responden. Sampel penelitian ini diambil dari individu yang menggunakan salah satu e-wallet dan mengetahui semua e-wallet selain yang digunakan, yaitu sebanyak 137 responden. 


\section{Definisi Operasional}

a. Manfaat

Manfaat merupakan suatu penghadapan yang semata mata menunjukan kegiatan menerima.

b. Keamanan

Keamanan secara umum merupakan sebuah faktor yang didalamnya terkait dengan infrastruktur teknis dan pelaksanaan, keadaaan yang aman sesuai dan dapat berkaitan dengan kerangka hukum untuk transaksi elektronik. Keamanan terwujud dengan memberikan terhadap dari penipuan dan privasi.

c. Kemudahan penggunaan

Kemudahan penggunaan merupakan suatu produk atau jasa mudah dipelajari, simpel, dipahami dan mudah dioperasikannya

\section{HASIL DAN PEMBAHASAN}

\section{Uji Validitas}

Semua item pernyataan pada atribut manfaat, keamanan dan kemudahaan penggunaan. Nilai $r$ hitung tersebut melihat dari Corrected Item-Total Correlation, nilai tersebut adalah nilai validitas butir. Dapat dikatan valid apabila memiliki nilai $r$ hitung lebih besar dari $r$ tabel, dalam hal ini nilai $r$ tabel adalah DF $=\mathrm{N}-2=>$ DF $=$ $137-2=135, r$ tabel pada DF 135 probabilitas 0,05 sebesar 0.1678 . Sehingga dapat dikatakan bahwa pernyataan yang membentuk atribut manfaat adalah valid dan dapat digunakan untuk analisis selanjutnya.

Tabel 1

Hasil Uji Validitas

\begin{tabular}{lclll} 
No. & \multicolumn{1}{c}{ Pernyataan } & r hitung & r tabel & Keterangan \\
X1.1 & Top up saldo e-wallet dapat melalui berbagai & 0.592 & 0,1678 & Item Valid \\
bank via ATM, mobile banking, internet banking, & & & \\
Booth, dan Gerai Ritel. & & &
\end{tabular}


X1.2 E-Wallet ini dapat digunakan transaksi di $0.552 \quad 0,1678$ Item Valid berbagai merchant secara online.

X1.3 E-Wallet ini banyak memberikan promo $0.827 \quad 0,1678$ Item Valid cashback.

X1.4 E-Wallet ini paling baik dalam memberikan $0.740 \quad 0,1678$ Item Valid reward berupa saldo maupun poin.

X1.5 E-Wallet ini banyak memberikan voucher. $\quad 0.688 \quad 0,1678 \quad$ Item Valid

X1.6 E-Wallet ini bermanfaat dalam pembayaran $0.719 \quad 0,1678$ Item Valid tagihan seperti tagihan telepon, listrik, PDAM, cicilan, dan lainnya.

X2.1 E-Wallet ini menyimpan data pribadi (privacy) $0.653 \quad 0,1678$ Item Valid dengan tidak menyalahgunakannya.

X2.2 E-Wallet ini menyimpan dan menjaga uang $0.777 \quad 0,1678$ Item Valid dengan baik.

X2.3 E-Wallet ini menampilkan laporan transaksi $0.751 \quad 0,1678$ Item Valid secara real time.

X2.4 E-Wallet ini memiliki kehandalan dalam $0.746 \quad 0,1678$ Item Valid menyediakan layanan pembayaran elektronik.

\begin{tabular}{llllll}
\hline No. & \multicolumn{2}{c}{ Pernyataan } & r hitung & r tabel & Keterangan \\
\hline X3.1 & E-wallet ini sangat mudah di download & 0,725 & 0,1678 & Item Valid \\
& menggunakan app store maupun play store. & & & \\
& & & & \\
\hline X3.2 & Menu dalam e-wallet sangat informatif, dilihat & 0,834 & 0,1678 & Item Valid \\
& dari berbagai layanan transaksi.
\end{tabular}


X3.3 Tampilan keseluruhan e-wallet ini user friendly. $\quad 0,833 \quad 0,1678 \quad$ Item Valid

X3.4 Riwayat transaksi dapat mudah ditemukan $0,765 \quad 0,1678$ Item Valid
pengguna.

Sumber: Data diolah

\section{Uji Reabilitas}

Semua atribut telah diuji Reabilitas bahwa Manfaat, Keamanan dan Kemudahan Penggunaan memiliki nilai cronbach alpha lebih dari 0,60. Sehingga dapat dikatakan ketiga atribut penelitian tersebut adalah reliabel.

\section{Tabel 2}

\section{Hasil Uji Reliabilitas}

\begin{tabular}{llcc}
\hline No. & Atribut & Nilai Cronbach Alpha & Keterangan \\
\hline 1. & Manfaat & 0,897 & Reliabel \\
\hline 2. & Keamanan & 0,892 & Reliabel \\
\hline 3. & Kemudahaan Penggunaan & 0,886 & Reliabel
\end{tabular}

Sumber: Data diolah.

\section{Hasil Analisis Korespondensi}

Guna mengetahui posisi persaingan ewallet, maka dilakukan analisi peta presepsi (perceptual mapping). Salah satu analisis multivariat yang digunakan dalam menentukan peta persepsi (perceptual mapping) adalah analisis korespondensi (correspondence analysis). Analisis korespondensi dapat digunakan untuk mencari pengelompokkan yang homogen dari individu. Output yang diperoleh berupa perceptual mapping yang terbagi atas beberapa dimensi. Minimal terbentuk atas dua dimensi ruang yang yang dapat dijadikan bahan analisis. Dari kedekatan antar objek tersebut dapat saling bersaing atau tidak. Berikut hasil dari analisis korespondensi, 


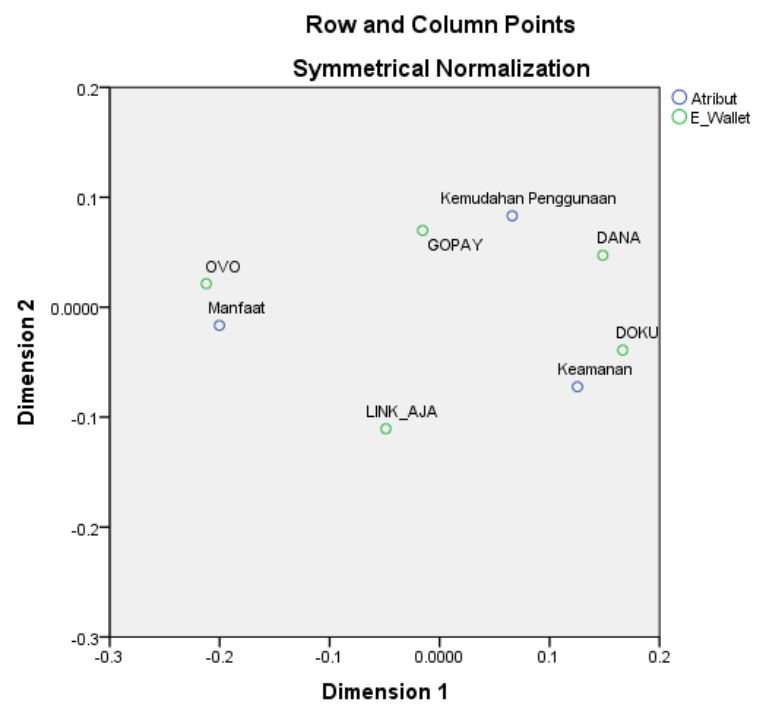

Gambar 2: Hasil Analisis Korespondensi

Berdasarkan hasil analisis dengan menggunakan analisis korespondensi, menunjukan bahwa positioning e-wallet, yang ditinjau dari atribut-atribut e-wallet masing-masing e-wallet memiliki keunggulan masing-masing yang tidak dimiliki oleh tempat e-wallet yang lain. Labelling Dimenssion diperoleh titik terbaik dari masing masing atribut pada d1 adalah keamanan, serta $d 2$ adalah kemudahaan penggunaan. Pada atribut manfaat dapat telihat posisi antar e-wallet dari jarak pada dimensi, bahwa posisi OVO lebih unggul dari e-wallet lainnya, atribut keamanan dapat telihat posisi antar e-wallet dari jarak pada dimensi, bahwa posisi DOKU lebih unggul dari e-wallet lainnya, atribut kemudahan penggunaan dapat telihat posisi antar e-wallet dari jarak pada dimensi, bahwa pada e-wallet GOPAY dan DANA menunjukan kedekatan dengan atribut tersebut, kedua e-wallet ini dinilai oleh konsumen memiliki kemiripan dalam hal keunggulan yang diusungnya. GOPAY diketahui bahwa e-wallet tersebut memiliki kemudahaan penggunaan yang paling baik diantara atribut yang lain. Pada OVO diketahui bahwa e-wallet tersebut memiliki manfaat yang paling baik diantara atribut yang lain. LINK AJA cenderung dipersepsikan oleh konsumen dalam kondisi netral diantara keamanan dan kemudahan penggunaan karena e-wallet ini dipandang masih baru berada di Indonesia. DOKU diketahui bahwa e-wallet tersebut memiliki keamanan yang paling 
baik diantara atribut yang lain.. DANA diketahui bahwa e-wallet tersebut memiliki kemudahan penggunaan yang paling baik diantara atribut yang lain.

\section{SIMPULAN}

1. positioning e-wallet, yang ditinjau dari atribut-atribut e-wallet masing-masing e-wallet memiliki keunggulan masing-masing

2. Dimensi (d1) adalah keamanan, serta Dimensi (d2) adalah kemudahaan penggunaan.

3. Pada taribut manfaat yang terbaik adalah e-wallet OVO, pada atribut keamanan adalah DOKU, serta pada atribut kemudahaan penggunaan adalah GOPAY dan DANA. E-wallet LINK AJA masih dipersepsikan netral.

\section{REFERENSI:}

Batari dkk. 2018. Pengaruh Kualitas Pelayanan dan Citra Merek terhadap Kepuasan Konsumen Mobil Ford. SEIKO: Journal of Management and Business. Vol.2(1), 1.

Bungin, Burhan. 2011. Metode Penelitian Kuantitatif. Edisi 2. Surabaya: Kencana Prenada Group.

Dac-Nhuong Le dkk (eds.). 2019. Cyber Security in Parallel and Distributed Computing. Scrivener Publishing LLC:Vietnam. Hal. 245-262.

Desy Yuliastuti. 2017. 3 Era Perkembangan Digital Payment di Indonesia .http://www.digination.id/read/01513/3-era-perkembangan-digital-payment-diindonesia Dikunjungi pada tanggal 17 Maret 2019.

Hair dkk. 2014. Multivariate Data Analysis. Seventh Edition. England and Associated Co: England.

Hawkins, Del I. and Mothersbaugh, David L. 2013. Consumer Behavior Twelfth Edition. McGraw-Hill.

Kotler, Philip and Armstrong, Gary. 2018. Principles of Marketing, Global Edition, 17 Edition, USA: Pearson Education.

Kotler, Philip and Keller, Kevin Lane. 2016. Marketing Mangement, Global Edition, 15e Edition, USA: Pearson Education. Erlangga. 
Marketing.co.id. 2018. Millennial Indonesia Lebih Sukai Transaksi Nontunai. https://marketing.co.id/millennial-indonesia-lebih-sukai-transaksi-nontunai/ Dikunjungi pada tanggal 10 Maret 2019.

Pangastuti, Anissa dkk. 2013. Pemetaan Persepsi Merk Laptop Di Kalangan Mahasiswa Menggunakan Analisis Korespondensi Berganda(Studi kasus: Mahasiswa Universitas Diponegoro Semarang).Prosiding Seminar Nasional Statistika, Semarang: Universitas Diponegoro.

Ruisa Khoiriyah. 2017. 5 Perbedaan E-Money dan E-Wallet Ini Perlu Kamu Ketahui. https://www.halomoney.co.id/blog/mengenal-perbedaan-uang-elektronik-emoney-dan-e-wallet. Dikunjungi pada tanggal 21 Maret 2019.

Sanghita Roy, Dr. Indrajit Sinha. 2014. Determinants of Customers' Acceptance of Electronic Payment System in Indian Banking Sector - A Study. International Journal of Scientific \& Engineering Research, Volume 5, Issue 1, January2014179 ISSN 2229-5518.

Sari Ferika. 2019 . Hingga November 2018, transaksi uang elektronik tembus Rp 5,19 triliun. Kontan https://keuangan.kontan.co.id/news/hingga-november2018-transaksi-uang-elektronik-tembus-rp-519-triliun Dikunjungi pada tanggal 12 Maret 2019.

Schiffman, L. G. \& Kanuk, L. L. 2010. Consumer Behavior. 10th ed. Upper.

Sindhi Aderianti. 2018. Berbagai e-Wallet alias Dompet Digital yang Sedang Tren di Indonesia. https://www.cekaja.com/info/berbagai-e-wallet-alias-dompetdigital-yang-sedang-tren-di-indonesia/ Dikunjungi pada tanggal 20 Maret 2019.

Syahputra, B. 2014. Analisis Positioning Jasa Transportasi Travel Bandung- Jakarta PP Berdasarkan Persepsi Pelanggan di Kota Bandung. Jurnal Manajemen Indonesia, Vol. 14(2): 128-139.

Teoh dkk. 2013. Factors affecting consumers' perception of electronic payment: an empirical analysis. Internet Research. Volume 23.Issue.24.pp.465-485

Yuliana, R. 2013. Analisis Strategi Pemasaran Pada Produk Sepeda Motor Matik Berupa Segmentasi, Targeting, dan Positioning serta Pengaruhnya Terhadap Keputusan Pembelian Konsumen di Semarang. Jurnal STIE Malang. Vol. 5, No. 2, Juni 2013.

Zukhrufah DA. 2018. 5 Produk e-Wallet Paling Populer di Indonesia. https://review.bukalapak.com/finance/5-produk-e-wallet-paling-populer-diindonesia-84685 . Dikunjungi pada tanggal 12 Maret 2019. 